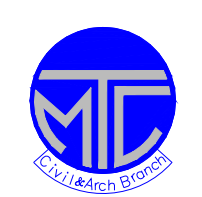

ICCAE

Military Technical College Kobry Elkobbah, Cairo, Egypt
7 th International Conference On Civil \& Architecture

Engineering

\title{
PROJECT MANAGEMENT TECHNIQUE CONCEPT AND EVALUATION
}

\section{ABSTRACT}

\section{Col. Dr. Ahmed Fahmy Farag.}

Project management (PM) is the despline of planning, organizing and managing available resources to bring about the successful completion of specific project goals and objectives.

A project is a finite end over undertaken to create a unique product or service.

The lecture aims to introduce engineering to the basic definitions and evaluations of PM technique as the primary challenge of PM is to Achieve all the project goals and objectives. While adhering to the classic project constrains (cost, time, quality). 